\title{
Preplant and postemergence herbicide treatments for weed control in direct-seeded and transplanted calabaza (Cucurbita moschata) ${ }^{1}$
}

\author{
Nelson Semidey² and Agenol González-Vélez ${ }^{3}$
}

J. Agric. Univ. P.R. 90(3-4):207-213 (2006)

\begin{abstract}
Two field experiments were conducted at the Corozal Agricultural Experiment Station, Puerto Rico, in 2000 and 2001 to evaluate four herbicide treatments in direct-seeded and transplanted calabaza [Cucurbita moschata Duchesne (Poir)] cv. Soler. Herbicide treatments were 1) glyphosate (1.75 L/ ha) preplanting (PP); 2) glyphosate (1.75 L/ha, PP) followed by sethoxydim ( $0.31 \mathrm{~kg}$ ai/ha) postemergence from five to nine weeks after planting; 3) clomazone ( $0.50 \mathrm{~kg}$ ai/ha, PP); 4 ) mixture of clomazone $(0.50 \mathrm{~kg}$ ai $/ \mathrm{ha})+\mathrm{glypho}$ sate (1.75 L/ha, PP); and 5) control with hand-weeded cultivation. Predominant weeds in the experimental area were large crabgrass [Digitaria sanguinalis (L.) Scop.], jungle rice [Echinochloa colona (L.) Link], wild poinsettia (Euphorbia heterophylla L.), and niruri (Phyllanthus niruri L.). At three and six weeks after planting, grasses and total weed density were usually higher in $\mathbf{2 0 0 0}$ than in 2001. In 2000, preplant clomazone alone or in mixture with glyphosate was more effective than glyphosate alone in reducing grasses and total weed densities at three weeks after planting. Differences in weed densities in general were non-significant among herbicide treatments in 2001. Also in 2001 hand-hoe cultivation was more effective reducing grasses and total weeds than preplant mixture of glyphosate plus clomazone or preplant glyphosate alone. Differences in weed dry weight at the end of the season as well as in calabaza yields were non-significant for herbicide treatments. Transplanted calabaza produced higher mean yields than direct-seeded calabaza both years. This result indicates that transplanted calabaza may compete better than direct-seeded calabaza under low weed population levels (two to 23 plants per $0.5 \mathrm{~m}^{2}$ ), given the advantage of the early establishment of transplants before appearance of weeds.
\end{abstract}

Key words: clomazone, glyphosate, sethoxydim

\section{RESUMEN}

Tratamientos de herbicidas presiembra y postemergentes para el control de malezas en siembra directa y de trasplante de calabaza (Cucurbita moschata)

En 2000 y 2001 se realizaron dos experimentos de campo en la Estación Experimental Agrícola de Corozal, Puerto Rico, para evaluar cuatro trata-

${ }^{1}$ Manuscript Submitted to Editorial Board 5 April 2006.

${ }^{2}$ Weed Scientist, Crop Protection Department, Agricultural Experiment Station, University of Puerto Rico, HC-01 Box 11656, Lajas, PR 00667.

${ }^{3}$ Horticulturist, Horticulture Department, HC-02 Box 10322, Corozal, PR 00783. 
mientos de herbicidas en siembra directa y de trasplante de calabaza [ $\mathrm{Cu}$ curbita moschata Duchesne (Poir)] cv. Soler. Los tratamientos de herbicidas fueron 1) glifosato $(1.75 \mathrm{~L} / \mathrm{ha})$ presiembra; 2$)$ glifosato $(1.75 \mathrm{~L} / \mathrm{ha}$, presiembra en secuencia con sethoxydim $(0.31 \mathrm{~kg}$ ia/ha) postemergente de cinco a nueve semanas después de la siembra; 3$)$ clomazone $(0.50 \mathrm{~kg}$ ia/ha) presiembra; 4) mezcla de clomazone $(0.50 \mathrm{~kg}$ ia/ha) + glifosato $(1.75 \mathrm{~L} / \mathrm{ha})$ presiembra; y 5) control manual con azada. Las malezas predominantes en el área experimental fueron pendejuelo [Digitaria sanguinalis (L.) Scop.], arrocillo [Echinochloa colona (L.) Link], leche vana (Euphorbia heterophylla L.), y quinino del pobre (Phyllanthus niruri L.). La densidad de gramíneas y el total de malezas fueron mayores en el 2000 que en el 2001, a las tres y seis semanas después de la siembra. Durante el 2000 , la densidad de gramíneas y el total de malezas a las tres semanas fue menor con el uso de clomazone presiembra, solo o en mezclas con glifosato, que con el glifosato solo. No hubo diferencias significativas $(P<0.05)$ entre tratamientos de herbicidas para las densidades de malezas durante el 2001. El cultivo manual con azada fue más efectivo en reducir las gramíneas y el total de malezas que el glifosato solo como presiembra durante 2001. Las diferencias en el peso seco de malezas al final de la cosecha, así como las diferencias en los rendimientos de calabaza, no fueron significativas entre los tratamientos de herbicidas. En ambos años, la calabaza trasplantada produjo un rendimiento mayor que la calabaza de siembra directa, lo que indica que la calabaza trasplantada puede competir mejor con las bajas densidades de malezas (dos vs. 23 plantas por $0.5 \mathrm{~m}^{2}$ ) encontradas, dada la ventaja de las plántulas de establecerse antes que las malezas.

Palabras clave: clomazone, glifosato, sethoxydim

\section{INTRODUCTION}

Weeds are difficult to control mechanically a few weeks after the emergence of vine-type crops such as calabaza (Cucurbita moschata). Two frequent weed management practices for this crop on the south coast of Puerto Rico are the use of plastic mulches and herbicides. In the central region, calabaza is usually grown on soils with steep slopes and scarce supplemental irrigation, thus making it more difficult to use plastic mulches. Therefore, chemical weed control becomes an important practice in this region. According to field studies conducted by Guzmán-Pérez (1986) calabaza requires a weed-free period for the first four to six weeks after planting for optimum fruit yields. Hence, weed control tactics must be employed to reduce weed interference during the critical period immediately after calabaza planting.

At present, bensulide, sethoxydim, glyphosate, and paraquat are the only registered herbicides for calabaza in Puerto Rico (Alvarado, 2006). Of these chemicals, only bensulide ( $\operatorname{Prefar}^{\mathrm{R}} 4-\mathrm{E}$ ), with limited efficacy to prevalent weeds in local production areas, is registered preemergence to calabaza. In the past, few efforts have been directed to evaluate different chemicals for weed control in calabaza. In one field study, the mixture of bentazon + fluazifop postemergence in sequential application after preemergence chloramben, metolachlor, and DCPA improved grass weed control up to $100 \%$ in calabaza, compared with lower effi- 
cacy obtained with the same herbicides applied alone (Liu et al., 1992). Control of broadleaves was not improved with the above mentioned herbicide mixtures (Liu et al., 1992). In previous experiments we reported that in order to obtain acceptable yields of cucurbits such as watermelon, cucumber and calabaza, a hand-weeding treatment was usually needed before or after the application of preemergence chloramben and DCPA (Semidey et al., 1986). In this study, bensulide provided poor weed control for four weeks, but calabaza yield was acceptable.

Bipyridilium herbicides diquat and paraquat were evaluated for postemergence control of weeds in tropical pumpkin at the Lajas Agricultural Experiment Station (Almodóvar et al., 1988). Diquat proved to be a potential herbicide for pumpkin since it controlled broadleaves with less toxic effect than paraquat. However, with diquat as well as paraquat pumpkin yield was similar to that with the hand-weeded control. Preplant applications of clomazone and oxyfluorfen reduced weed densities by over $90 \%$ and increased cabbage yield beyond that of the non-treated control in several field trials (Semidey, 1997; Semidey et al., 1999). On the basis of previous results with clomazone and oxyfluorfen in cabbage, an evaluation of these herbicides was also conducted with calabaza (Semidey, 2002). Clomazone preplanting provided the best weed control in calabaza for the first three weeks. Neither of these two herbicides has been registered for weed control in calabaza in $\mathrm{Pu}-$ erto Rico. Performance of clomazone deserves further evaluation for its efficacy in combination with registered glyphosate in calabaza.

New approaches with existing herbicides must be developed for weed control in calabaza. One approach to increase the early vigor and yield of this crop could be the use of transplants instead of direct-seeding. Olsen et al. (1994) reported an increase in early growth and yield of watermelon from transplants. However, Buker et al. (2003) reported that transplanting watermelon did not increase its competitive ability against yellow nutsedge (Cyperus esculentus L.). The objective of this study was to evaluate preplant glyphosate and clomazone, each one alone and in mixture, and a preplant application of glyphosate in sequence with postemergence sethoxydim in both direct-seeded and transplanted calabaza.

\section{MATERIALS AND METHODS}

Two field experiments were conducted at the Corozal Agricultural Experiment Station to evaluate four herbicide treatments and handweeded cultivation in direct-seeded as well as in transplanted calabaza (cv. Soler) in 2000 and 2001. The soil was a Corozal clay (very-fine, parasesquic, isohyperthermic Typic Hapludults) with $\mathrm{pH} 5.7,2.28 \%$ or- 
ganic matter, $61.53 \%$ clay, $21.76 \%$ silt and $16.71 \%$ sand. A randomized complete block design was initially followed for the five herbicide treatments and four replications, modified to split-plots for the two methods of planting (direct seeding and transplanting). Main plots (for herbicide treatments) measured $11.0 \mathrm{~m}$ by $9.1 \mathrm{~m}$, with four rows of calabaza, 1.83 $\mathrm{m}$ apart. Subplots were $3.65 \mathrm{~m}$ wide by $9.1 \mathrm{~m}$ long with 10 calabaza plants. Herbicide treatments were 1$)$ glyphosate $(1.75 \mathrm{~L} / \mathrm{ha})$ preplanting (PP); 2) glyphosate (1.75 L/ha, PP) followed by sethoxydim $(0.31 \mathrm{~kg}$ ai/ha) postemergence (POE); 3) clomazone ( $0.50 \mathrm{~kg}$ ai/ha, $\mathrm{PP})$; and 4$)$ mixture of clomazone $(0.50 \mathrm{~kg}$ ai/ha $)+$ glyphosate $(1.75 \mathrm{~L} / \mathrm{ha}, \mathrm{PP})$.

Clomazone and glyphosate were applied one to two days before planting. Sethoxydim was sprayed over the top at five and seven weeks after planting (WAP) in 2000 and seven and nine WAP in 2001. An untreated control with hand-weeded cultivation at planting and another weeding at five to six WAP was also included. Planting dates for calabaza were 1 March 2000 and 12 January 2001. Weed density (plants per $0.5 \mathrm{~m}^{2}$ ) for individual species was recorded at 3 and $6 \mathrm{WAP}$, and total weed dry weight at 16 to 17 WAP. Phytotoxicity was visually rated on a scale from 0 to 100 on 10 calabaza plants, where $0=$ no injury and $100=$ complete stand kill at 3 WAP during the 2000 experiment. Calabaza fruits were usually harvested from 16 to 18 WAP, and yield was determined for subplots.

\section{RESULTS AND DISCUSSION}

Predominant weeds in the experimental area were the two grasses, large crabgrass (Digitaria sanguinalis) and jungle rice (Echinochloa colona); and the two broadleaves, wild poinsettia (Euphorbia heterophylla L.) and niruri (Phyllanthus niruri). Year by treatment interaction was significant for density of grasses and total weeds at 3 WAP (Table 1). Slight crop injury was recorded three weeks after clomazone application during 2000 , but calabaza seedlings recovered and no injury symptoms were noticed at 6 WAP (data not presented). Similar results were reported by Liu et al. (1992) in a loamy Mollisol soil. Density of grasses and total weeds were usually higher in 2000 than in 2001. Broadleaf density was low and non-significant for all herbicide treatments both years. Grasses and total weeds were more efficiently reduced with preplant clomazone alone and clomazone plus glyphosate treatment than with hand-weeded cultivation or with glyphosate alone. Weed densities in general were non-significant among treatments at 3 WAP during 2001.

Year by treatment interaction was significant for density of broadleaves, grasses, and total weeds at 6 WAP (Table 2). In 2000, preplant 
TABLE 1. Year by herbicide treatment interaction for broadleaves, grasses and total weed density three weeks after planting calabaza at Corozal, Puerto Rico, during 2000 and 2001. ${ }^{1}$

\begin{tabular}{|c|c|c|c|c|c|c|c|}
\hline \multirow[b]{2}{*}{ Treatment $^{3}$} & \multirow[b]{2}{*}{ Rate } & \multicolumn{2}{|c|}{ Broadleaves $^{2}$} & \multicolumn{2}{|c|}{ Grasses } & \multicolumn{2}{|c|}{ Total weeds } \\
\hline & & 2000 & 2001 & 2000 & 2001 & 2000 & 2001 \\
\hline & & \multicolumn{6}{|c|}{ 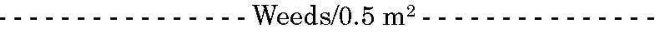 } \\
\hline Glyphosate PP & $1.75 \mathrm{~L} / \mathrm{ha}$ & 5 & 2 & $15 \mathrm{~b}$ & $0 \mathrm{c}$ & $20 \mathrm{~b}$ & $2 \mathrm{c}$ \\
\hline Glyphosate PP & $1.75 \mathrm{~L} / \mathrm{ha}$ & 6 & 3 & $15 \mathrm{~b}$ & $3 \mathrm{c}$ & $21 \mathrm{~b}$ & $6 \mathrm{c}$ \\
\hline Clomazone PP & $0.50 \mathrm{~kg} / \mathrm{ha}$ & 1 & 2 & $0 \mathrm{e}$ & $0 \mathrm{c}$ & $1 \mathrm{e}$ & $3 \mathrm{c}$ \\
\hline Clomazone + & $0.50 \mathrm{~kg} / \mathrm{ha}$ & & & & & & \\
\hline Glyphosate PP & $1.75 \mathrm{~L} / \mathrm{ha}$ & 2 & 3 & $0 \mathrm{c}$ & $0 \mathrm{c}$ & $2 \mathrm{c}$ & $7 \mathrm{c}$ \\
\hline \multicolumn{2}{|c|}{ Hand-weeded cultivation ${ }^{4}$} & 6 & 2 & $24 \mathrm{a}$ & $0 \mathrm{c}$ & $30 \mathrm{a}$ & $4 \mathrm{c}$ \\
\hline
\end{tabular}

${ }^{1}$ Average of two samples, two planting methods, and four replications. Means in or within columns followed by the same letter are not significantly different according to Pvalues $(\mathrm{P}<0.05)$ using Least Square Mean for year by herbicide treatment effect.

${ }^{2}$ Year by herbicide treatment interaction was non-significant for broadleaf density.

${ }^{3} \mathrm{PP}=$ preplanting.

${ }^{4} \mathrm{Hand}$-hoed at planting and once again five to six weeks later.

clomazone alone or in mixture with glyphosate was as effective as hand-hoe cultivation for broadleaf control and more efficacious than glyphosate treatments. As in early evaluation, differences in broadleaf

TABLE 2. Year by herbicide treatment interaction for broadleaves, grasses, and total weed density six weeks after planting calabaza at Corozal, Puerto Rico, during 2000 and $2001 .^{I}$

\begin{tabular}{|c|c|c|c|c|c|c|c|}
\hline \multirow[b]{2}{*}{ Treatment $^{2}$} & \multirow[b]{2}{*}{ Rate } & \multicolumn{2}{|c|}{ Broadleaves } & \multicolumn{2}{|c|}{ Grasses } & \multicolumn{2}{|c|}{ Total weeds } \\
\hline & & 2000 & 2001 & 2000 & 2001 & 2000 & 2001 \\
\hline & & \multicolumn{6}{|c|}{ - Weeds $/ 0.5 \mathrm{~m}^{2}-\ldots$} \\
\hline Glyphosate PP & $1.75 \mathrm{~L} / \mathrm{ha}$ & $7 \mathrm{~b}$ & $4 \mathrm{c}$ & $14 \mathrm{a}$ & 1 de & $21 \mathrm{a}$ & $5 \mathrm{c}$ \\
\hline Glyphosate PP fb & $1.75 \mathrm{~L} / \mathrm{ha}$ & & & & & & \\
\hline Sethoxydim $\mathrm{POE}^{3}$ & $0.31 \mathrm{~kg} / \mathrm{ha}$ & $9 a$ & $5 \mathrm{c}$ & 14 a & $4 \mathrm{c}$ & $23 a$ & $9 \mathrm{~b}$ \\
\hline Clomazone PP & $0.50 \mathrm{~kg} / \mathrm{ha}$ & $1 \mathrm{c}$ & $3 \mathrm{c}$ & $0 \mathrm{e}$ & $1 \mathrm{de}$ & $2 \mathrm{c}$ & $4 \mathrm{c}$ \\
\hline Clomazone + & $0.50 \mathrm{~kg} / \mathrm{ha}$ & & & & & & \\
\hline Glyphosate PP & $1.75 \mathrm{~L} / \mathrm{ha}$ & $2 \mathrm{c}$ & $4 \mathrm{c}$ & $0 \mathrm{e}$ & $3 \mathrm{~cd}$ & $2 \mathrm{c}$ & $9 \mathrm{~b}$ \\
\hline \multicolumn{2}{|c|}{ Hand-weeded cultivation ${ }^{4}$} & $2 \mathrm{c}$ & $3 \mathrm{c}$ & $6 \mathrm{~b}$ & $0 \mathrm{e}$ & $8 \mathrm{~b}$ & $3 \mathrm{c}$ \\
\hline
\end{tabular}

\footnotetext{
${ }^{1}$ Average of two samples, two planting methods, and four replications. Means in or within columns followed by the same letter are not significantly different according to Pvalues $(\mathrm{P}<0.05)$ using Least Square Mean for year by herbicide treatment effect.

${ }^{2} \mathrm{PP}=$ preplanting, $\mathrm{POE}=$ postemergence, $\mathrm{fb}=$ followed by.

${ }^{3}$ Sethoxydim was applied over the top five and seven weeks after planting (WAP) in 2000, seven and nine WAP in 2001.

${ }^{4}$ Hand-hoed at planting and once again five to six weeks later.
} 
density at 6 WAP were non-significant among treatments during 2001. During 2000, preplant clomazone, either alone or in mixture with glyphosate, reduced grasses and total weed densities more than glyphosate alone or in sequence with sethoxydim. The first sethoxydim application was delayed until 5 and 7 WAP during 2000 and 2001, respectively, all of which did not contribute to reducing grass density. Hand-hoe cultivation was more effective reducing grasses and total weed density than preplant glyphosate in mixture with clomazone. Both years, total weed density after herbicide treatments can be considered low for competition level against calabaza, which is considered a strong crop competitor against weeds because of its climbing growth habit (Guzmán-Pérez, 1986).

Differences in weed dry weight at the end of the season as well as calabaza yields were non-significant among treatments (Table 3). Year by planting method interaction was significant for calabaza yield (Table 4). During both years transplanted calabaza produced higher yields than direct-seeded. Yield of transplanted calabaza was higher in 2001 than in 2000 probably because of lower weed density and thus less interference in 2001 than in 2000. Our results may indicate that transplanted calabaza competed better over weeds than direct-seeded calabaza, probably because of its establishment earlier than appearance of weeds. These results are in agreement with findings of Olson et al. (1994) using watermelon transplants.

TABLE 3. Weed dry weight and calabaza yield for herbicide treatments at Corozal, Puerto Rico during 2000 and $2001 .^{1}$

\begin{tabular}{|c|c|c|c|c|c|}
\hline \multirow[b]{2}{*}{ Treatment $^{3}$} & \multirow[b]{2}{*}{ Rate } & \multicolumn{2}{|c|}{ Weed dry weight ${ }^{2}$} & \multicolumn{2}{|c|}{ Calabaza yield } \\
\hline & & 2000 & 2001 & 2000 & 2001 \\
\hline & & \multicolumn{2}{|c|}{$-\ldots-g / 0.5 \mathrm{~m}^{2}-\ldots$} & \multicolumn{2}{|c|}{$\ldots$} \\
\hline Glyphosate PP & $1.75 \mathrm{~L} / \mathrm{ha}$ & 71 & 80 & 3,650 & 6,740 \\
\hline Glyphosate PP fb & $1.75 \mathrm{~L} / \mathrm{ha}$ & & & & \\
\hline Sethoxydim POE & $0.50 \mathrm{~kg} / \mathrm{ha}$ & 48 & 55 & 6,270 & 7,480 \\
\hline Clomazone PP & $0.50 \mathrm{~kg} / \mathrm{ha}$ & 55 & 70 & 8,580 & 8,730 \\
\hline Clomazone + & $0.50 \mathrm{~kg} / \mathrm{ha}$ & & & & \\
\hline Glyphosate PP & $1.75 \mathrm{~L} / \mathrm{ha}$ & 56 & 53 & 11,920 & 12,120 \\
\hline Cultivation ${ }^{4}$ & - & 47 & 50 & 8,785 & 11,450 \\
\hline
\end{tabular}

\footnotetext{
${ }^{1}$ Average of two planting methods and four replications. Year by herbicide treatment interaction and the main effect of treatment were non-significant for weed dry weight and calabaza yield.

2Total weed dry weight sampled 16 to 17 weeks after planting.

${ }^{3} \mathrm{PP}=$ preplanting, $\mathrm{POE}=$ postemergence, $\mathrm{fb}=$ followed by sethoxydim five and seven weeks after planting (WAP) in 2000, seven and nine WAP in 2001.

${ }^{4}$ Hand-hoed at planting and once again five to six weeks later.
} 
TABLE 4. Interaction of planting method and year for calabaza yield at Corozal, Puerto Rico, during 2000 and 2001.

\begin{tabular}{|c|c|c|}
\hline \multirow[b]{2}{*}{ Planting method } & \multicolumn{2}{|c|}{ Calabaza yield $^{1}$} \\
\hline & 2000 & 2001 \\
\hline & - . - - & $\ldots$ \\
\hline Direct-seeded & $5,205 \mathrm{c}$ & $3,455 \mathrm{c}$ \\
\hline Transplanted & $10,480 \mathrm{~b}$ & $15,230 \mathrm{a}$ \\
\hline
\end{tabular}

${ }^{1}$ Average of five treatments and four replications. Means in or within columns followed by the same letter are not significantly different according to $\mathrm{P}$-values $(\mathrm{P}<0.05)$ using Least Square Mean for year by planting method effect.

\section{LITERATURE CITED}

Almodóvar, L., M. Díaz-Rivera and N. Semidey, 1988. Evaluation of diquat for postemergence weed control in pumpkin. J. Agric. Univ. P.R. 72:285-290.

Alvarado, A., 2006. Base de datos: Plaguicidas con premiso de uso en P.R. Herbicidas 2005-2007. University of Puerto Rico-Mayagüez, Agricultural Extension Service. Available at $\mathrm{http}: / /$ academic.uprm.edu/aalvarado.

Buker III, R. S., W. M. Stall, S. M. Olson, and D. G. Shchilling, 2003. Season-long interference of yellow nutsedge (Cyperus esculentus) with direct-seeded and transplanted watermelon (Citrullus lanatus). Weed Technol. 17:751-754.

Guzmán-Pérez, C. D., 1986. Períodos críticos de competición y efectos alelopáticos de algunas malezas en calabaza y berenjena. M.S. Thesis. Univ. of P.R., Mayagüez Campus.

Liu, L. C., E. Caraballo, I. Reyes-Soto and N. Acín, 1992. Chemical weed control in calabaza. J. Agric. Univ. P.R. 76:55-61.

Olson, S. M., G. J. Hochmuth and R. C. Hochmuth, 1994. Effect of transplanting on earliness and total yield of watermelon. HortTechnology. 4: 141-143.

Semidey, N., 2002. Clomazone and oxyfluorfen as preplant herbicides for Cucurbita moschata (calabaza). J. Agric. Univ. P.R. 86:73-75.

Semidey, N., A. González and A. Aponte, 1999. Application timing for clomazone and oxyfluorfen in transplanted cabbage. J. Agric. Univ. P.R. 83: 175-180.

Semidey, N., 1997. Clomazone and oxyfluorfen for weed control in transplanted cabbage (Brassica oleracea L.). J.Agric. Univ. P.R. 81: 203-210.

Semidey, N., L. Almodóvar and I. Reyes, 1986. Herbicide evaluation in three cucurbits. J. Agric. Univ. P.R. 70:85-90. 